\title{
Methods for Estimation of Multiplier Effect of Investments in Development of Infrastructure of Inland Water Transport in the Russian Federation in the Frameworks of Federal Target Programs
}

\author{
Tatyana Alekseevna Pantina ${ }^{1} \&$ Svetlana Anatolyevna Borodulina $^{2}$ \\ 1 Admiral Makarov State University of Maritime and Inland Shipping, Department of economy of the water \\ transport, Saint Petersburg, the Russian Federation \\ 2 Saint-Petersburg state university of Economics, Engineering and Economics Faculty, Department of \\ transportation systems management, Saint Petersburg, the Russian Federation \\ Correspondence: Pantina Tatyana, Dvinskaya str., 5/7, St. Petersburg, 198035, the Russian Federation.
}

\author{
Received: March 11, 2015 Accepted: March 30, $2015 \quad$ Online Published: May 22, 2015 \\ doi:10.5539/res.v7n9p83 URL: http://dx.doi.org/10.5539/res.v7n9p83
}

The study was conducting in the frameworks of research scientific work made in 2014 by the order of Federal Marine and River Transport Agency of Department of the Transportation of the Russian Federation.

\begin{abstract}
The offered method for estimation of influence of investments in development of infrastructure of inland waterways provided by Transport strategy of the Russian Federation for the period up to 2030 and Federal target program "The development of transportation system of the Russian Federation (2010-2020s)" on growth of economy of Russia allows estimating the integral multiplier effect. In the study there are methodological approaches and estimations of multiplier effect of investments in realization of number of major investment projects for liquidation of limiting sites on Single Deep-Water System (SDWS) of European part of Russia with use of transport and production multipliers. The offered method provides detalization of economic effect when forecasting and control for realization of Federal target programs on water transport. The mechanism of estimation of branch effect offered by authors is detailed in sources of gaining economic growth in a branch (the direct and indirect branch effect) and allied branches that helps to get the notion of objectives and forecasts of their development for the period of program validity and subsequent period of objects' operation. There is also a graphic structural diagram that provides considering the structure of multiplier effect and following the interrelation of indicators - the estimation elements. The offered algorithm of estimation of single multiplier effect elements provides discerning the sequence and the way of estimation of main effectiveness indicators of Federal target programs. In the paper there are also the results of estimation by offered diagram with use of software on the data of Federal target program "Development of transportation system of the Russian Federation (2010-2020s)" and Transport strategy of the Russian Federation for the period up to 2030 designed by the authors. Using the results of estimations we have also performed the quantitative estimation of multiplier effect of investments in liquidation of limiting sites on SDWS that makes up $1295 \mathrm{bln}$. rbs.
\end{abstract}

Keywords: investments, multiplier effect, transport multiplier, production multiplier, branch effect, federal target programs, inland water transport, Single Deep-Water System, infrastructure, fleet, shipments, cargos, passengers

\section{Introduction}

The transport branch of Russia, in which there are large-scale investment projects realized, is being the source of welfare of country's population, decrease of unemployment level, provides objective conditions for functioning and development of other branches of economy, leads to the growth of branch and social effectiveness.

The major investment projects on transport generate the influxes of funds to budget of the country, have high level of social and economic effect of their realization that is reflected in getting branch (direct and indirect) effect and extra-transport effect (the effect of allied branches). In this connection it is reasonably to define the economic effect with use of multiplier effect elements.

The goal of the present study is the estimation of multiplier effect of investments in projects for liquidation of 
limiting sites on Single Deep-Water System (SDWS) of European part of the Russian Federation.

The significant problem is the imbalance of development of transportation system of Russia, presence of disproportions in temps and scales of development of various types of transport, including significant delay in development of river transport.

The negative trend of decrease of the role of inland water transport in the transportation system of Russia has arisen due to the rapid slump of volumes of freightage in comparison with 90s years of the previous century-it has made up 4.6 times (in 1989 it was more than $580 \mathrm{bln}$. tons). The structural changes in economy of the country, decrease of industrial construction volumes, mining of non-ore construction materials, development of pipelines network are the objective external factors of such a slump. At the same time one of the main factors for decrease of competitive ability and investment attraction of inland water transport is the deterioration of inland waterways infrastructure.

"For the recent 20 years the length of inland waterways with guaranteed sizes of navigable channels has reduced almost $30 \%$ (from 67 thous. $\mathrm{km}$. to 48.4 thous. $\mathrm{km}$.), the guaranteed depths were reduced throughout the length of 27.5 thous. $\mathrm{km}$. Due to the reduction of qualitative parameters of navigable channels the losses of freight capacity have made up about $80 \mathrm{mln}$. tons. The fifth part of shipping hydrotechnical structures is of insufficient safety level, even despite the significant improvement of their engineering status for the recent years" (Pantina, 2011).

In the European part of the country there is unparalleled Single Deep-Water system with length of 6.5 thous. km., the waterways of which are used for transportation of about $70 \%$ of total volume of river transport and where there are main export-import freight traffics.

The presence of limiting sites, so-called "bottlenecks", does not allow using its huge potential to the full extent. The critically limiting sites that significantly limit its carrying capacity are: Lower Svir sluice on the Volga-Baltic waterway, Gorodets-Balakhna site on the lower Volga in the area of Nizhny Novgorod, Saralevsky water node on the lower Volga, the site from Kochetovcky hydroelectric complex to Aksay on the lower Don.

The investments in liquidation of limiting sites allow increasing of carrying capacity of inland waterways, volumes of freights and passengers' transportation that will promote the growth of branch's incomes and generate associated incomes of allied branches, provide gain of population employment.

The reallocation of freight traffic from land types of transport to more economic and ecological inland water transport will lead to reduction of aggregate expenditures for maintenance of transport infrastructure of the country, negative influence of transport on environment and also reduction of losses due to the high load of number of land (primarily — automobile) highways.

In the study there are analysis of methods for estimation of multiplier effect conducted, methodology for its estimation, estimations of direct economic effect (for inland water transport), multimodal effect (for allied types of transport), allied branches effect and measurement of budget earnings gain performed.

\section{Literature Review}

The assessment of the impact of investments on economy of countries was researched by many scientists, among whom we should mention the founders of multiplier effect Richard Kahn (1931) and John Maynard Keynes (1936; 1973). In their works it is said that the result of investments in economy is so-called multiplier effect, which is expressed in much bigger increase of result in comparison with performed current investments that can lead to significant growth of economy and standard of living of population. The matters of multiplier effect in Keynes economy are considered in the work of Anderson D. (1997). Besides, the multiplier theory got development in the research of Rodney Maddock and Michel Carter (1989). The theory of Keynes J. suggests that there is the necessity for increase in investment activity in economy by the way of performance of state investments. According to the data of researches conducted by Clark, Colin M. (1938) the multiplier effect in economy can be defined with use of indicators that were taken by the way of processing of official statistics.

Scientists of Russia actively use the present methods and models. In particular, Shirov (2012) states that the multiplier effect is understood to be "the performance of production volumes (investments) as per corresponding branch multiplier that reflects the integral effect when increasing indicators of branch with account of its contribution to economic growth." In the works of Shirov one can find the data about multipliers in the most important sectors of Russian economy. The multiplier in economy is considered to be numerical coefficient showing how many times the result indicators of economy development in case of growth of investments or production in a branch will change (the study of "Center for strategic elaborations" fund, 2013). Titov (2010) also considers the impact of innovations on economic growth of a country by the way of getting effects of 
multiplier and synergetic types.

The assessment of the impact of transportation branch on macroeconomy by means of estimation of multiplier effects is considered in the works of number of researchers. Thus, Marazzo, Marcial and Scherre, Rafael and Fernandes, Elton (2010) found strong connection between the demand for air transportation and gross domestic product (GDP) of Brazil. According to assessments of Azele Mathieu and Bruno Van Pottelsberghe (2005), the values of air transport multiplier makes 2.1 for the effect of employment growth, 2.2 for added value and 1.6 for the income of government budget of Belgium.

Kenneth Button and Junyang Yuan (2013) examined the role of air transportations in stimulation of local and regional economic growth (in the sphere of employment and incomes) in the USA. The analysis was conducted on the basis of using information of 35 airports in the USA from 1990 to 2009 and it proves that the air transportations were the positive impetus for development of local economy. Oosterhaven and Stelder (2002) specified the possibility of applying branch multipliers in estimation of economic growth of country, having excluded the probability of double counting effects for the transportation branch of the Netherlands. McArthur, David Philip and Thorsen, Inge and Jan (2013) offered a new model of assessment of impact of investments in transportation infrastructure on allocation of work positions in the agricultural sector and proved the increase of regional development indicators. Abdulai, Awudu and Johnson, Michael and Diao, Xinshen (2006) studied the dynamics of growth of the agricultural sector of Africa when realizing government investments and political reforms for attraction of external growth effects. They made conclusion about significant multiplier effect of innovations and proved that reduction of trade barriers and growth of international transportations will generate $10 \%$ increase of incomes from the agricultural sector. Fleming, David A. and Measham, Thomas G. (2014) used regional multipliers for assessment of impact of investments in mining industry of Australia on the incomes generated in other sectors of economy. In the researches of "Center for strategic elaborations" fund (2013) there is an example of estimation of multiplier effects of realization of major infrastructural projects for development of railway transport of Russia.

In many countries the significant consideration is given to the development of inland water transport. The researches of Seidenfus, Hellmuth St. (1994) concerning the sphere of inland water transport witness that in Germany the special attention is paid to its development against the background of growth of infrastructural bottlenecks in railway and automobile transportations, ecological consequences and expenses for supply chains. The Conference of transport ministers (held in Rotterdam in 2001) and the Bucharest pan-European conference on inland water transport (2006) adopted number of recommendations that should support and stimulate the development of inland water transport in European countries. The committee on inland water transport of European economic commission of United Nations Organization (EEC UN) constantly conducts thorough researches dedicated to prospects of inland navigation in the frameworks of united Europe. Thus, under the auspices of EEC UN "The white book on effective and stable inland water transport in Europe" (2011) was issued, where there are priority areas of its strategic development.

At the present time in the Russian Federation the realization of advantages of inland water transport is refrained by number of factors, among which there are: presence of limiting sites on inland waterways, unfavorable age composition of fleet and deficit of modern ships, loading and off-loading complexes and port terminals, rapid decrease of innovative elaborations in the sphere of technology and organization of transportation process, rollback of operations on interrelation with other types of transport, absence of researches on application of effective organization of shipment logistics network, absence of system of organizational, economical and institutional measures aimed at attraction of freights and passengers to inland water transport, etc. The total negative impact of above-mentioned factors stipulates low investment attraction of branch's enterprises, slump of volumes of transportation of freights and passengers, negative trends in change of the structure of transported freights (Pantina, 2011). In this connection the matters of budget investments in above-mentioned infrastructure objects of inland waterways and system estimation of probable effect due to such contributions are being highly relevant.

The results of research of published literature sources witness the significant interest in methodological and practical aspects for defining multiplier effect, actuality of conducting assessment of impact of investments performed in various branches of economy, including transportation branch and separate types of transport, on increase of GDP of the country and other macroeconomic indicators. In general, when analyzing modern publications we have not found the made estimations of multiplier effect of investments due to the contributions into infrastructure of inland water transport that, however, is being rather important element in the system of transportation branch management and substantiation of reasonability of investment in objects of infrastructure of inland waterways. 
The presence of "bottlenecks" within waterways of Single Deep-Water System of European part of Russia leads to the increase of costs of production and reduction of competitiveness of river transportations preventing ship-owners from realization of long-term investment programs for fleet building.

The analysis of affairs provided by strategic documents for transportation branch development aimed at liquidation of "bottlenecks" of SDWS of European part of Russia, such as Federal target program called "The development of transportation system of Russia (2010-2020s)" with "Inland water transport" subprogram (the decree of Government of the Russian Federation, 2009, 2014), Transportation strategy of the Russian Federation for the period up to 2030 (edict of Government of the Russian Federation 2008, 2014), has shown that in the sphere of inland water transport the Government had initiated the following projects: "Construction of the second toe of Lower Svir sluice (2012-2017)"-in 2014 the works at two top-priority stages (construction of cargo terminal including access and aquatorium) were finished; "Construction of low-head water power development of Nizhny Novgorod (2016-2020)", "Construction of Bagaevsky low-head water power development (2015-2020)".

The Gorodets-Nizhny Novgorod site is being a linking node for large freight traffic formed in the direction of from the basin of Kama, mid- and lower Volga regions to the Baltic. In the period of navigation it provides passability of about 10000 ships, which transport about $13 \mathrm{mln}$. tons of freights. The expectation of additional water pass through Gorkovsky hydrosite for provision of necessary depths leads to standstill of more than 1300 ships with $6 \mathrm{mln}$. freights at an average for three days. On the site there are continuous water level sittings, this year the situation has become harder due to the lack of water. Due to the limitations for sitting ships for navigation in 2014 (at the beginning of navigation the pass-through draught of ships was no more than $2.6 \mathrm{~m}$., starting from August 11 -no more than $2.0 \mathrm{~m}$.) the thorough navigation of large-capacity and tourist fleet on Volga was practically disrupted.

In consequence of redistribution of freight traffic when reducing volumes of transportations across the Volga-Baltic waterway in 2014 the intensity of navigation and, respectively, the standstill of ships on the Volga-Don waterway (in the period of peak loads - up to 6 days) have significantly increased. Experts estimate the additional losses of shipping companies on Gorodets-Nizhny Novgorod site approximately $1 \mathrm{bln}$. rbs. and of the country as a whole-20 bln. rbs. (REGNUM information agency, 2014). Summarizing all the above-mentioned matters we can state that the realization of project of construction of hydroelectric complex of Nizhny Novgorod is being of importunate necessity in the nearest years.

At the modern stage the Volga-Don waterway is the most loaded part of Single Deep-Water System of European part of Russia, where there is stable growth of freight traffic - the factual volumes of freights transportation in 2008 made $7.1 \mathrm{mln}$. tons, in 2012-11.4 mln. tons, in 2013-12.5 mln. tons (Pantina, 2014). What if for navigation of 2014 - the freight traffic has increased up to $14.5 \mathrm{mln}$. tons.

The base of ships passing the channel is presented with ships with cargo carrying capacity of more than 5000 tons. As a result of excess of carrying capacity of sluices every day about 60 ships are in for sluicing, the standstill of ships increases. The site of Lower Don from Kochetovsky hydroelectric complex to Aksay is the most inconvenient site for navigation. The pass-through draught here is $3.2 \mathrm{~m}$., while in low water years it hardly reaches $2.7 \mathrm{~m}$. The summarized losses of fleet transportation capacity due to the deficient use of cargo carrying capacity makes, according to assessment of shipping companies, more than $2.6 \mathrm{mln}$. tons.

The construction of Bagaevsky hydroelectric complex is provided in innovative variant of Transportation strategy of the Russian Federation for the period up to 2030.

The Volga-Don waterway possesses specific significance in the system of latitudinal and meridional international transportation corridors. The prediction estimates of transportations across the channel show that freight traffic of foreign trade and transit freights (oil products, metal, sulphur, fertilizers, etc.) have huge potential of growth that cannot be realized due to the depletion of its carrying capacity. That is why the matter of construction of the second toe of sluices of Volga-Don navigation channel becomes more and more relevant.

The economic justification of reasonability of realization of such large-scale investment projects implies use of adequate methodological instruments.

The necessity for improving methods for estimation of effectiveness of investment projects on transport as the basis for provision of economic interrelations at the scale of national and world economy is stipulated with its fundamental features, which objectively define the presence of various and significant in scales external effects of projects realized in the present branch. 


\section{Methodology}

The methodology for estimation of multiplier effect of investments in liquidation of limiting sites within inland waterways of SDWS is based on the following backgrounds and interrelations. The budget investments in liquidation of the present sites are aimed at increase of volumes of transportations by inland water transport, i. a. by means of reallocation of freight traffic between different types of transport, growth of investment activity in the branch, foremost - of shipping business, and also generate increase of production in allied branches of economy. As a result of projects' realization the increase of final demand in economy is expected, what will positevely influence the social and economic parameters of development of population, business and country as a whole.

The contributions in development of infrastructure of inland water transport of Russia imply budget investments in limiting sites of SDWS (Ib) and also off-budget investments in renewal of fleet (Ip).

In our mind, to estimate the effects of realization of major branch projects one should use the following multipliers - the multiplier of investments in construction of transportation infrastructure $(\mathrm{CM})$, the multiplier of production growth in the " rolling stock production" form of activity (PM), the multiplier of freightage volumes (transhipping traffic) growth $(\mathrm{QM})$. For this purpose it will be reasonably to use the model on the basis of interindustry balance realized in the Institute of national economy forecasting of the RAS (the research of "Center for strategic elaborations" fund, 2013). In this respect the increase (decrease) of prospect transportation volumes will lead to growth (reduction) of potential production volumes in allied branches being the consumers of transportation services. Using the estimated multiplier values and the data of investment program (project) one can get the quantitative estimations of effects due to their realization in economy.

The justification of effectiveness of projects for development of transportation infrastructure requires for estimation of several types and indicators of effectiveness united in a system.

The estimation of effect of investment in major infrastructural projects on water transport in Russia imply estimation of its components at the stages of construction and operation of objects. Here we also have a multiplier effect in allied branches of economy, among which there are: construction industry, extraction industry, processing enterprises, metallurgy, metalworking, production of machines and equipment, production of transport facilities, electric power industry and water supply, finances and insurance, trade and other. The estimation of transportation effect is based on growth of volumetric indicators of inland water transport (the volumes of transportation of freights, passengers, the volumes of freights' transshipping in ports) and other types of transport-in such a case the earnings gain taken by allied branches of economy also increases.

The schematic diagram for estimation of project's effectiveness is presented in figure 1 . 
Multiplier effect of project's realization

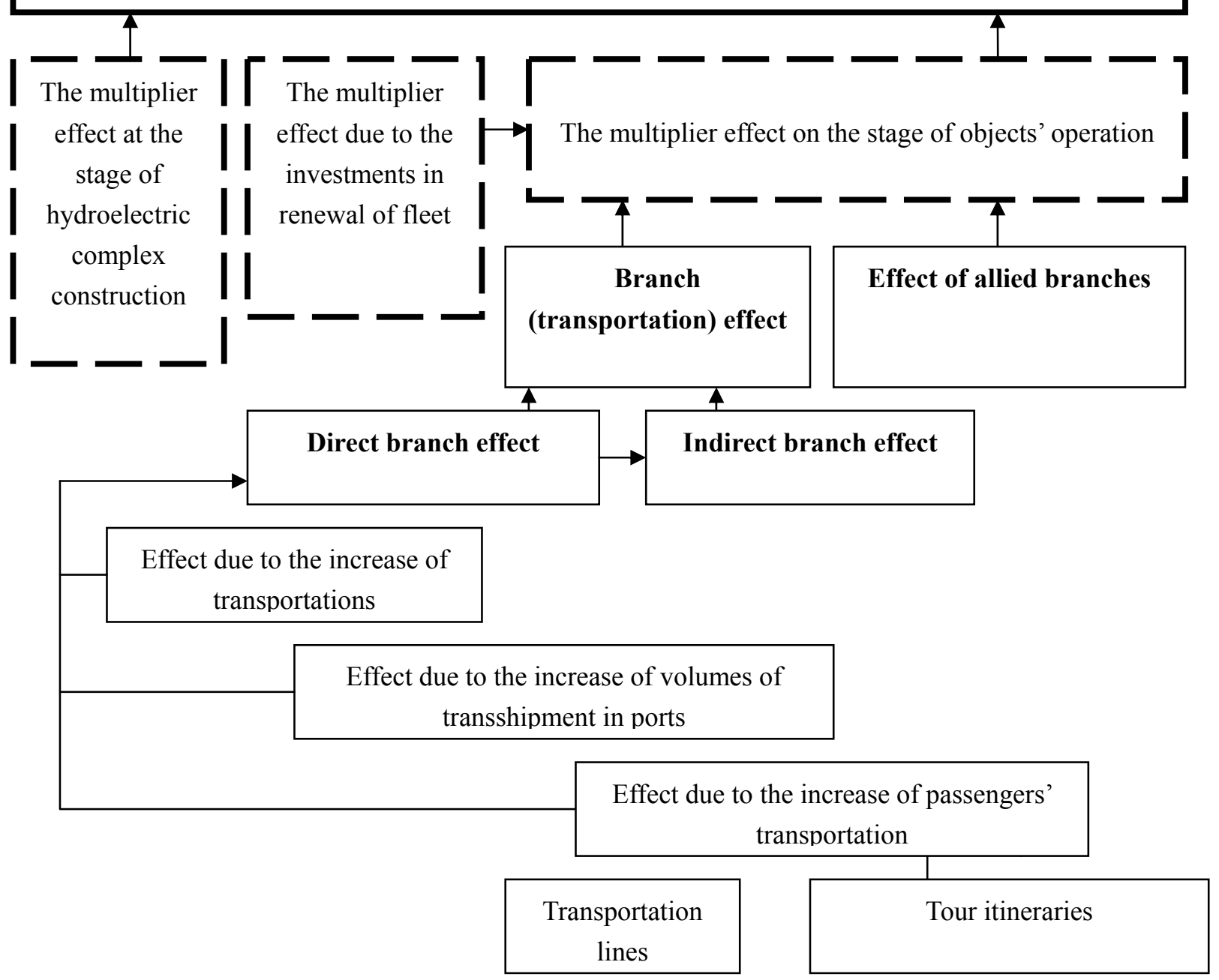

Figure 1. The schematic diagram for estimation of project's effectiveness

The multiplier effect accounts the consequences of project's realization for society as a whole, i.e.- -in the sphere of transport activity (the transport effect) and also extra transport effect (the effect of allied branches). The branch (transport) effect includes the effect for shipping companies, ports and enterprises of other transport types.

The components of direct branch effect are: the growth of volumes of transportation of freights and passengers by inland water transport, the increase of volume of freight transshipment in ports. The indirect branch economic effect (the multimodal effect) is generated in a branch due to more efficient realization of strategic advantages of inland water transport as the most ecological and economical type of transport and also due to reallocation of a part of freight traffic from above-ground transport to inland water transport in the period of navigation. The indirect (multimodal) branch effect covers: the relative reduction of current expenses for maintenance of transportation infrastructure; the decrease of overall negative impact of transportation complex on environment; the reduction of standstill of rolling stock due to the high load of a number of above-ground (primarily-automobile) highways, etc. The components of branch (transport) economic effect are presented in figure 2 . 


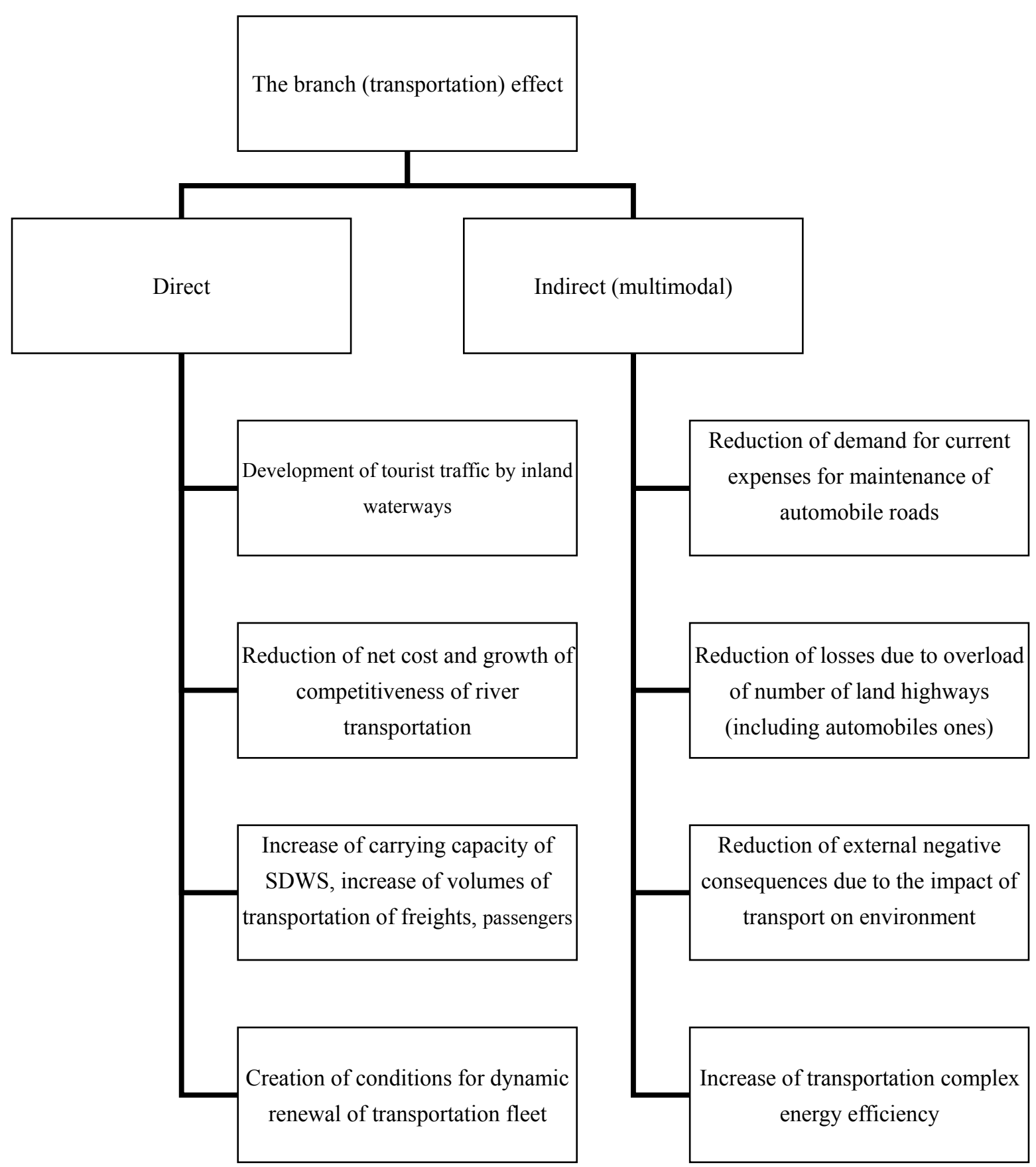

Figure 2. The components of branch (transportation) economic effect

The indicators of effectiveness of investments are listed in table 1. 
Table 1. The indicators of effectiveness of investments in the projects for liquidation of limiting sites on SDWS

\begin{tabular}{|c|c|c|}
\hline Indicator & Formula & Comments \\
\hline $\begin{array}{l}\text { 1. The volume of budget } \\
\text { investments (Ib) in projects for } \\
\text { liquidation of limiting sites on } \\
\text { SDWS (in current money terms) }\end{array}$ & $I \mathrm{~b}=\sum_{i=1}^{n} \frac{I b_{i}}{(1+r)^{i}}$ & $\begin{array}{l}\mathrm{i} \text { - the current year of project's } \\
\text { realization; } \\
\mathrm{r} \text { - discount rate (taken as equal to } \\
\text { the crediting rate on long-range }\end{array}$ \\
\hline $\begin{array}{l}\text { 2. The volume of off-budget } \\
\text { investments (Ip) in fleet renewal } \\
\text { (in current money terms) }\end{array}$ & $I \mathrm{p}=\sum_{i=1}^{n} \frac{I p_{i}}{(1+r)^{i}}$ & $\begin{array}{l}\text { operations of the Bank of Russia or } \\
\text { the refinancing rate); } \\
\mathrm{n} \text {-the duration of settlement } \\
\text { period. }\end{array}$ \\
\hline $\begin{array}{l}\text { 3. Gross output in economy (B1) } \\
\text { due to budget investments in } \\
\text { projects for liquidation of limiting } \\
\text { sites on SDWS }\end{array}$ & $\hat{A} 1=\sum_{i=1}^{n} \frac{I b_{i}}{(1+r)^{i}} \bullet C M$ & $\begin{array}{l}\mathrm{CM} \text {-the multiplier of investments } \\
\text { in construction. }\end{array}$ \\
\hline $\begin{array}{l}\text { 4. Gross output in economy (B2) } \\
\text { due to off-budget investments in } \\
\text { fleet renewal }\end{array}$ & $B 2=\sum_{i=1}^{n}\left(\frac{I p_{i}}{(1+r)^{i}} \bullet\right.$ & $\begin{array}{l}\text { PM-the multiplier of production } \\
\text { growth in the "production of } \\
\text { rolling stock" form of activity for } \\
\text { water transport (shipbuilding). }\end{array}$ \\
\hline
\end{tabular}

5. The multiplier effect at the stage $\quad M E 1=B 1-I b$

of hydroelectric complexes

construction (ME1)

6. The branch (transport) effect (T) $\quad T=D T+I M$

\begin{tabular}{ll}
\hline 6.1 Direct branch effect (DT) & $D T=T 1+T 2+T 3$ \\
\hline $\begin{array}{l}\text { As a result of increase of } \\
\text { freightage volume (T1) }\end{array}$ & $\mathrm{T} 1=\sum_{i=1}^{n}\left(Q_{i} \cdot d_{o} \frac{\left(1+\mathrm{K}_{\mathrm{i}}\right)^{\mathrm{i}}}{(1+\mathrm{r})^{\mathrm{i}}}\right)$
\end{tabular}

Qi-the forecasting increase of volumes of freights' transportation within SDWS as a result of project's realization;

do - the base revenue rate (as per volume unit of transportation);

$\mathrm{ki}$ - the forecasting inflation rate.

- As a result of increase of port transshipment volumes (T2)
Q1i-the forecasting increase of volumes of transshipment of freights in river ports;

$\mathrm{d} 1 \mathrm{i}$ - the base revenue rate (as per volume unit of transshipment).

$\begin{aligned} & \text { As a result of } \quad \begin{array}{r}\text { passenger } \\ \text { volumes }\end{array} \\ & \begin{array}{l}\text { transportation } \\ \text { (transportation lines, tourist traffic) }\end{array}\end{aligned} \quad T 3=\sum_{i} \sum_{j}\left(Q p_{i j} \cdot d p_{0 j} \frac{\left(1+\mathrm{k}_{\mathrm{i}}\right)^{i}}{(1+\mathrm{r})^{\mathrm{i}}}\right)$
$(\mathrm{T} 3)$

Qpij-the annual increase of volumes of transportation of passengers (by types of transportations);

dpoj-the average tariff for transportation of one passenger (by types of transportations) in base year;

$\mathrm{j}$ - the type of transportations (transportation lines $j_{1}$, tourist traffic $\mathrm{j}_{2}$ ). 


\begin{tabular}{|c|c|c|}
\hline (IM) & & branch effect. \\
\hline $\begin{array}{l}\text { 7. Gross output in economy (V) } \\
\text { due to the growth of transportation } \\
\text { of freights and passengers, } \\
\text { transshipment of freights in ports } \\
\text { with account of allied branches } \\
\text { effect }\end{array}$ & $V=T \cdot Q M$ & $\begin{array}{l}\text { QM-the multiplier of production } \\
\text { increase in the sphere of } \\
\text { transportation activity. }\end{array}$ \\
\hline $\begin{array}{l}\text { 8. The multiplier effect at the stage } \\
\text { of objects' operation (ME2) }\end{array}$ & $M E 2=M E t+M E n$ & \\
\hline $\begin{array}{l}8.1 \text { Due to the growth of } \\
\text { transportation of freights and } \\
\text { passengers, transshipment of } \\
\text { freights in ports (MEt) }\end{array}$ & $\mathrm{MEt}=\mathrm{V}-\sum_{\mathrm{k}=1}^{\mathrm{m}} \mathrm{CM}_{\mathrm{k}} \cdot \frac{\left(1+k_{i}\right)^{i}}{(1+r)^{i}} \cdot Q M$ & $\begin{array}{l}\mathrm{CM}_{\mathrm{k}} \text { - the material expenses; } \\
\mathrm{m}(1 \ldots 3) \text { - the number of types of } \\
\text { activities, on which the increase of } \\
\text { volume of works as a result of } \\
\text { project's realization is expected } \\
\text { (transportation of freights, } \\
\text { transshipment of freights in ports, } \\
\text { transportation of passengers). }\end{array}$ \\
\hline $\begin{array}{l}8.2 \text { Due to the investments in } \\
\text { construction of transport fleet } \\
\text { (MEn) }\end{array}$ & $M E n=B 2-I \kappa$ & $\begin{array}{l}\text { Ik-the subsidies from federal } \\
\text { budget for renewal of fleet, } \\
\text { including partial compensation of } \\
\text { interest rates on credits for } \\
\text { building of ships. }\end{array}$ \\
\hline
\end{tabular}

9. The summarized multiplier $M E=M E 1+M E 2$

effect of project (ME)

The indicators of material expenses listed in the table and used for estimation of multiplier effect of realization of major investment projects on water transport are calculated on the assumption of share of material expenses in output defined with help of statistical analysis of data and with due consideration of its differentiation on water transport by types of activity (transportation of freights, passengers, transshipment in ports) and other allied branches of economy.

\section{Results and Discussion}

On the basis of offered methodology the estimation of multiplier effect of investments in projects for liquidation of limiting sites on SDWS is performed: the construction of low-head water power development of Nizhny Novgorod on the mid-Volga, the construction of the second toe of Lower Svir sluice in the Volga-Baltic region, the construction of Bagaevsky low-head water power development on the Lower Don, the realization of which is planned in the frameworks of Transportation strategy of the Russian Federation for the period up to 2030 (the innovative variant).

According to the data given in Federal target program "The development of transportation system of Russia (2010-2020s)" with "Inland water transport" subprogram (2014) and Transportation strategy of the Russian Federation for the period up to 2030 (2014), the following volumes of budget investments in development of infrastructure of inland waterways of SDWS (table 2) and off-budget investments in renewal of fleet (table 3) are provided. 
Table 2. The investments from federal budget (innovative variant, with discounting), mln. rbs.

\begin{tabular}{lllllllllll}
\hline Year & $\mathbf{2 0 1 2}$ & $\mathbf{2 0 1 3}$ & $\mathbf{2 0 1 4}$ & $\mathbf{2 0 1 5}$ & $\mathbf{2 0 1 6}$ & $\mathbf{2 0 1 7}$ & $\mathbf{2 0 1 8}$ & $\mathbf{2 0 1 9}$ & $\mathbf{2 0 2 0}$ & Total \\
\hline $\begin{array}{l}\text { The hydroelectric } \\
\begin{array}{l}\text { complex of Nizhny } \\
\text { Novgorod }\end{array}\end{array}$ & 0 & 0 & 9 & 39 & 364 & 292 & 7251 & 9671 & 6341 & 23967 \\
$\begin{array}{l}\text { The Lower Svir } \\
\text { hydroelectric } \\
\text { complex }\end{array}$ & 220 & 382 & 129 & 1971 & 2312 & 3265 & 907 & 59 & 66 & 9311 \\
$\begin{array}{l}\text { Bagaevsky } \\
\text { hydroelectric } \\
\text { complex }\end{array}$ & 0 & 0 & 0 & 5960 & 5916 & 4754 & 3871 & 2884 & 0 & 23384 \\
\begin{tabular}{l} 
Total investments \\
\hline
\end{tabular} & 220 & 382 & 137 & 7970 & 8592 & 8310 & 12029 & 12614 & 6407 & 56662 \\
\hline
\end{tabular}

Table 3. The off-budget investments in renewal of (innovative variant, with discounting), mln. rbs.

\begin{tabular}{lllllllllll}
\hline Year & $\mathbf{2 0 1 2}$ & $\mathbf{2 0 1 3}$ & $\mathbf{2 0 1 4}$ & $\mathbf{2 0 1 5}$ & $\mathbf{2 0 1 6}$ & $\mathbf{2 0 1 7}$ & $\mathbf{2 0 1 8}$ & $\mathbf{2 0 1 9}$ & $\mathbf{2 0 2 0}$ & $\mathbf{2 0 2 1}$ \\
\hline $\begin{array}{l}\text { Total } \\
\text { Including }\end{array}$ & 24000 & 16000 & 17000 & 16000 & 28000 & 30000 & 26000 & 43000 & 46000 & 75000 \\
in SDWS & 19200 & 11824 & 11606 & 10091 & 16313 & 16146 & 12927 & 19750 & 19518 & 29397 \\
\hline Year & $\mathbf{2 0 2 2}$ & $\mathbf{2 0 2 3}$ & $\mathbf{2 0 2 4}$ & $\mathbf{2 0 2 5}$ & $\mathbf{2 0 2 6}$ & $\mathbf{2 0 2 7}$ & $\mathbf{2 0 2 8}$ & $\mathbf{2 0 2 9}$ & $\mathbf{2 0 3 0}$ & Total \\
\hline $\begin{array}{l}\text { Total } \\
\begin{array}{l}\text { Including } \\
\text { in SDWS }\end{array}\end{array}$ & 36000 & 106000 & 110000 & 118000 & 125000 & 131000 & 142000 & 144000 & 157000 & 1450000 \\
\hline
\end{tabular}

The calculation of money flows for estimation of direct economic effect of realization of complex of investment projects for construction and reconstruction of hydrotechnical structures for the purpose of liquidation of limiting sites on SDWS was made on the assumption of expected increase of volumes of transportation of freights (passengers) by inland water transport, volumes of transshipment of freights in ports and the revenue rate by types of transportations. The rate for discounting money flows was taken equal to the refinancing rate level of the Bank of Russia ( $8.25 \%$ in 2014).

The component elements of integral multiplier effect are:

- The multiplier effect of investments in projects for liquidation of limiting sites on SDWS-the investment multiplier is 2.05 (Shirov A. A., 2013-hereinafter without consideration of import component);

- The multiplier effect of ships building: due to additional investments in building of new ships as the consequence of increase of competitiveness and effectiveness of river transportations as a result of navigation conditions improvement - the multiplier of shipbuilding is 2.2 ;

- The multiplier effect due to the growth of freight and passenger transportations by inland transport types and transshipment in river ports - the transport multiplier is 1.75 .

The calculation is made with use of specially designed software for Excel that includes the following blocks:

- Basic data (design parameters, data of economic forecast, predictive and expert assessments for transportation volumes, economical indicators, expected expenses and results);

- Estimation of branch effect;

- Estimation of multiplier effect;

- Estimation of specific multiplier effect.

The components and the structure of direct branch effect are presented in figure 3 . 


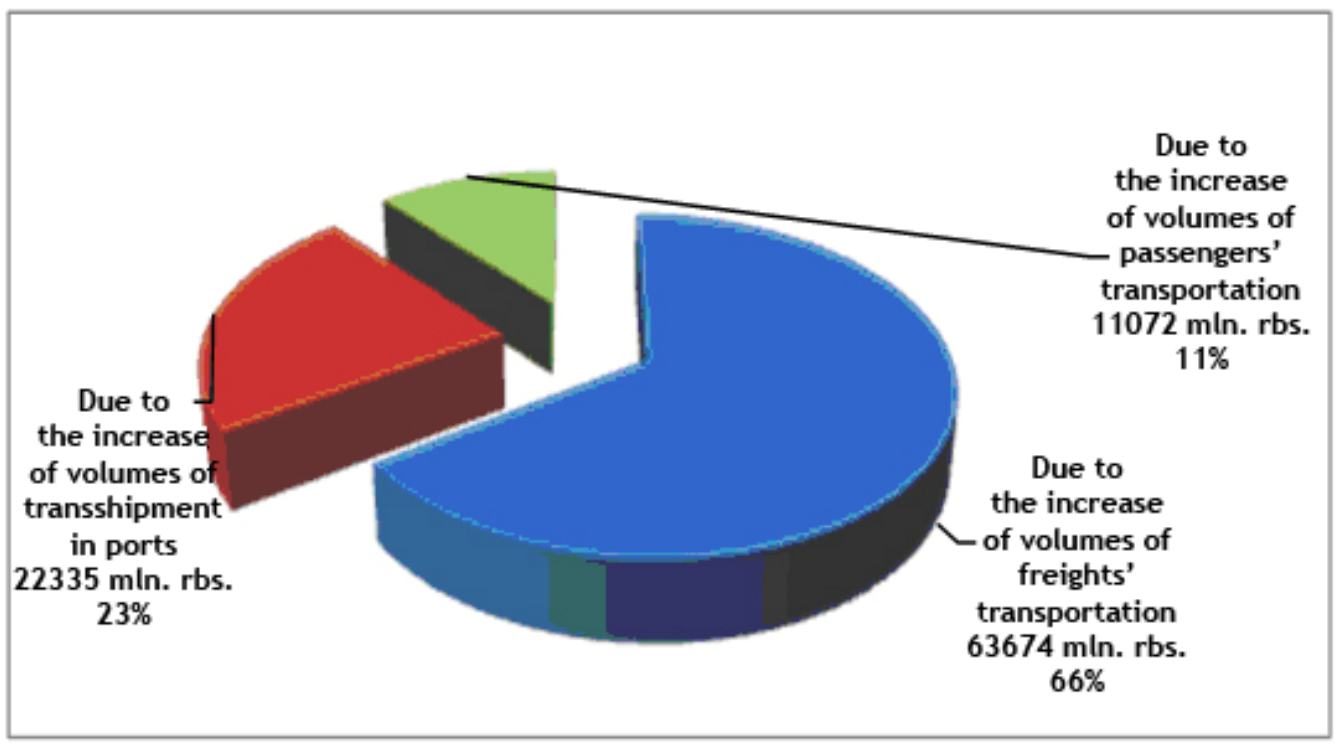

Figure 3. The components and the structure of direct branch effect

The multiplier effect (in terms of above-specified components) is defined by multiplication of the sum of increase of discounted money flows as per corresponding multiplier.

The calculation of money flows was made in current cost terms (the costs of corresponding years) with account of forecasted inflation level according to the data of Economic Development Ministry of Russia.

The multiplier effect is estimated at the stage of hydroelectric complexes' construction and at the stage of objects' operation. The estimation of the effect as a result of project's realization is made by years of accounting period with subsequent aggregation of the result:

1) The multiplier effect of investments in projects for liquidation of limiting sites is estimated by means of deduction from the sum of earlier calculated budget investments in infrastructural projects' gross output increase (with account of corresponding multiplier).

2) The multiplier effect of investments in renewal of fleet is estimated by means of deduction from the sum of gross output (with account of corresponding multiplier) of payments from federal budget for partial compensation of interest rates on credits for building of ships.

3) The multiplier effect of increase of volumes of transported freights, passengers and transshipment in ports is estimated as gross value added with account of effect for allied branches (the gross income minus material expenses with account of multiplier). The indirect branch (multimodal) effect was taken as the share from the direct effect defined on the basis of expert evaluation (taken equal to $20 \%$ ).

4) The total multiplier effect was estimated by summing up of listed components of money flows for the accounting period (2012-2030).

The verification of offered model that had proven its adequateness was performed.

Thus, the multiplier effect of investments in liquidation of limiting sites on SDWS estimated on the basis of presented methodology makes $1295 \mathrm{bln}$. rbs., including the multiplier effect of allied branches $-1179 \mathrm{bln}$. rbs. or more than $90 \%$ of total sum; while the branch effect makes $116 \mathrm{bln}$. rbs.

The specific multiplier effect of projects' realization makes almost 2.5 roubles as per one rouble of investments. Such a high value of the present indicator is stipulated with system solution of the problem of liquidation of "bottlenecks" on SDWS in the innovative variant of Transportation strategy that provides creation of necessary backgrounds for significant increase of effectiveness and competitiveness of transportations by inland waterways, as well as increase of investment attraction of the branch.

The results of estimation of GDP increase in Russia in case of realization of investment projects in infrastructure of inland water transport are presented in figure 4. 


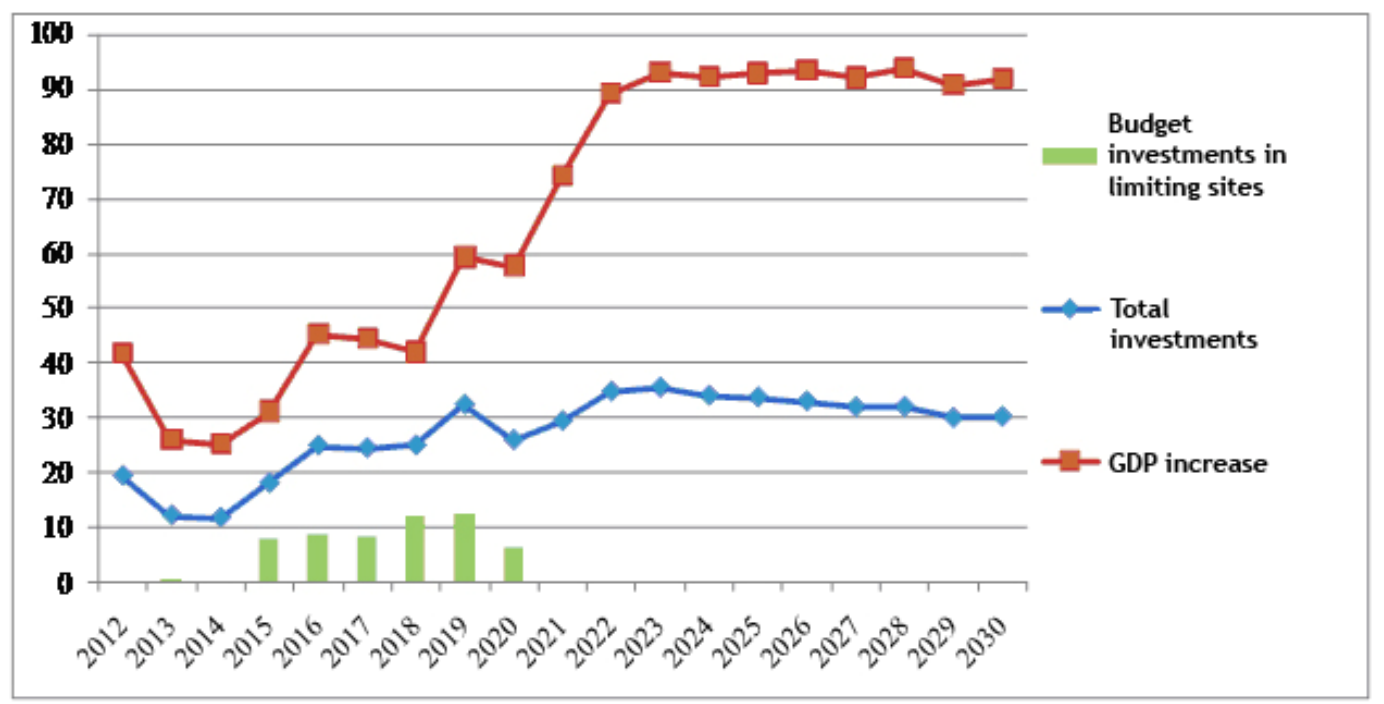

Figure 4. Increase of GDP as the result of projects' realization

The offered methodology possesses practical significance and can be used for conduction of investment projects estimation on the macroeconomic level of branch management.

In our estimation we have used the multipliers' values substantiated by other researchers, in particular-by Shirov A. A., however it should be noted these values depend on great number of external factors, including the share of import production in expenses for construction, etc. In this connection it would be reasonably to specify the values of mentioned multiplier and the way of their estimation in the modern context of market change and geopolitical situation.

In the course of making estimations with use of offered methodology the predictive estimates of volumetric indicators for transportation of freights (passengers) in accordance with innovative variant of Transportation strategy were used; when realizing conservative variant the taken estimates will be much lower.

The distribution of generated increase of gross outputs and GDP by the types of activity won't be affine, as mainly it is defined by technological structure of investments, structure of branch's operating expenses and share of import production in expenses. Besides, in the estimations of multiplier effect there are no risks of specific projects, the estimation of which can correct the obtained results.

\section{Conclusion}

The realization of major infrastructure projects on inland water transport of Russia in the frameworks of Transport strategy requires development of relevant methods for complex estimation of investments' effectiveness, primarily — on the basis of federal budget funds.

In the course of research we have gained the following main conclusions:

1) It was proven that transportation branch of Russian, in which large-scale investment projects are realized, have significant influence on growth of other branches of economy and economic growth of the country as a whole.

2) The necessity for making budget investments in financing of infrastructure (liquidation of limiting sites of SDWS) and development of inland water transport is proven. The ways of getting effect when performing the specified projects is described.

3) The creation of mechanism for estimation of forecasting multiplier effect, the practicability of which is caused by the necessity for control and forecasting the results of budget investments when developing Federal target programs in the Russian Federation, is proven. It is shown that the offered mechanism and the methodology of estimation of effectiveness indicators can be used also for making estimation of investment projects on macroeconomic level for branch management.

4) The concept of multiplier effect is specified. Thus, the multiplier effect of large-scale investment projects on inland water transport can be determined by the way of estimation of branch (direct and indirect) effect and 
off-transport effect (the allied branches effect).

5) The application of investment, production and branch multipliers when realizing the offered mechanism of multiplier effect estimation is proven. Using the values of multipliers and the data of investment project the authors consider it possible to get quantitative estimation of effects of realization of specified projects on economy of Russia.

6) The offered mechanism of determining effect of investment in major infrastructural projects on water transport in Russia implies estimation of its components at the stage of construction and at the stage of objects' operation. The important element is the estimation of multiplier effect in allied branches of economy (construction branch, extraction industry, manufacturing activities, metallurgy, metalworking, production of vehicles and equipment, production of transport facilities, electric power industry and water supply, finances, insuring, etc.).

7) The authors have proven that estimation of branch (transport) effect should be based on programming growth of indicators of inlands water transport (volumes of transportation of goods, passengers, volumes of transshipment in ports) and other types of transport.

8) The structural scheme for estimation of influence of major investment projects on growth of economy of Russia is designed.

9) The system of indicators of effectiveness of investments in projects for liquidation of limiting sites on SDWS and the methodology of their estimation, which together present the mechanism of estimation of economic multiplier effect of realization of projects on inland water transport, are designed.

10) The authors have designed the software and presented the results of estimation of multiplier effect of realization of projects for liquidation of limiting sites on SDWS. For assessment of direct economic effect the authors have made estimation of money flows due to the realization of complex of investment in construction projects and reconstruction of hydrotechnical structures on the assumption of expected increase of volumes of transportation of freights (passengers) by inland water transport, volumes of transshipment of freights in ports and revenue rate by the types of transportations.

11) The verification of offered methodology for estimation of indicators of effectiveness of investments in the development of inland water transport is made. The multiplier effect due to the investments in liquidation of limiting sites on SWDS (that makes 1295 bln. rbs., including the multiplier effect of allied branches-1179 bln. rbs. and branch effect -116 bln. rbs.) is defined.

12) The value of specific multiplier effect due to the realization of projects that makes almost 2.5 roubles as per 1 rouble of investments is taken.

The offered methodology implies system estimation of overall multiplier effect due to budget and private investments in the projects for development of infrastructure of inland water transport on SDWS for economy of Russia. However, the present study should be extended in future by the assessment of impact of such projects on the economy of separate regions. To conduct such an assessment there should be the mechanism of distribution of generated incomes in transportation and allied branches, which would take into account the specifics and differentiation of regions in provision with labour force, availability of material resources, transport accessibility to territories, as well as distribution of input flow of investments in objects of transportation infrastructure of separate regions.

\section{References}

Abdulai, A., Johnson, M., \& Diao, X. (2006, December). Leveraging regional growth dynamics in African agriculture. African Journal of Agricultural and Resource Economics.

Anderson, D. (1997). The Multiplier Effect. In C. Thomas (Ed.), An Encyclopedia of Keynesian Economics (pp. 450-453). Cheltenham, UK: Edward Elgar.

Button, K., \& Yuan, J. (2013). Airfreight Transport and Economic Development: An Examination of Causality. (PDF-file). http://dx.doi.org/10.1177/0042098012446999

Clark, C. M. (1938). Determination of the Multiplier from National Income Statistics. The Economic Journal, 435-480. http://dx.doi.org/10.2307/2225436

Center for strategic elaborations fund: Large-scale infrastructure projects evaluation. (2013). Problems and solutions. In Developments within the framework of projects and decisions. Moscow. Retrieved from http://rzd.ru/dbmm/?col_id=121\&id=71716\&load=y\&vp=1 
Fleming, D. A., \& Measham, T. G. (2014). Local job multipliers of mining. http://dx.doi.org/10.1016/j.resourpol.2014.02.005

Government of the Russian Federation. (2008). Transport strategy the Russian Federation for the period until 2030 (p. 1734). Government edict of the Russian Federation.

Government of the Russian Federation. (2009, December 5). Concerning the federal special-purpose program "Development of transportation system of Russia" (2010-2020). In Decree of the Government of the Russian Federation (\# 848) (as in force on 15.05.2014\# 445, 30.09.2014 \# 995 and others).

Government of the Russian Federation. (2014, April 15). Concerning approval of the government program of the Russian Federation "Development of transportation systems". In Decree of the Government of the Russian Federation (\# 319).

Government of the Russian Federation. (2014, June 11). Concerning the Introduction of Amendments and Additions to Transport Strategy of the Russian Federation (p. 1032). Retrieved from http://www.zakonprost.ru/content/base/part/596074

Kahn, R. (1931). The Relation of Home Investment to Unemployment. The Economic Journal, $173-198$. http://dx.doi.org/10.2307/2223697

Keynes, J. M. (1936). The General Theory of Employment, Interest and Money.

Keynes, J. M. (1973). In D. Moggridge (Ed.), The Collected Writings of John Maynard Keynes. London: Cambridge University Press.

Maddock, R., \& Carter, M. (1989). The new macroeconoms: Several players. $\mathrm{ftp}: / / \mathrm{ftp}$. drivehq.com/cavasco/lecturas/numero29/n29a4.pdf

Marazzo, M., Scherre, R., \& Fernandes, E. (2010). Air transport demand and economic growth in Brazil: A time series analysis. http://dx.doi.org/10.1016/j.tre.2009.08.008

Mathieu, A., \& Van Pottelsberghe, B. (2005). The economic role of the aviation industry in Belgium. In Brussels Economic Review (pp. 393-418). ULB Universite Libre de Bruxelles.

McArthur, D. P., \& Inge, T., \& Ub ̃, e, J. (2013). Employment, transport infrastructure and rural depopulation: A new spatial equilibrium model (PDF-file). Retrieved from http://www.envplan.com/abstract.cgi?id=a46120

Oosterhaven, J., \& Stelde, D. (2002). Net Multipliers Avoid Exaggerating Impacts: With A Bi-Regional Illustration for the Dutch Transportation Sector. Journal of Regional science, 3, 553-543. http://dx.doi.org/10.1111/1467-9787.00270

PA REGNUM. (2014, July 23). Navigation is out of the level: Lack of water complicates shipping on the upper Volga. Retrieved from http://www.regnum.ru/news/polit/1828829.html6

Pantina, T. A. (2011). Vision and structural pattern of formation of development strategy of inland water transport of the Russian Federation for the period until 2030. Vestnik Gosudarstvennogo Universiteta Morskogo i Rechnogo Flota im. Admirala S. O. Makarova, 3, 166-170.

Pantina, T. A. (2014). Water ways of poor quality-Debottlenecking in inland water-ways of Russia. Rechnoy transport (21th century), 5(70).

Seidenfus, H. S. (1994). Inland waterway transport in the federal Republic of Germany: Situation and problems. Transportation Research (Part A). http://dx.doi.org/10.1016/0965-8564(94)90049-3

Shirov, A. A. (2012). Estimation of multiplier effect in economy. Possibilities and limitations. Retrieved from http://www.macroforecast.ru/doc/shirov_yantovsky.doc

Titov, L. Y. (2010). Synergetic and multiplier effect innovation networks. Audit i finansovy analiz, 2.

United Nations. (2011). White Paper on effective and sustainable inland water transport in Europe. New York and Geneva.

\section{Copyrights}

Copyright for this article is retained by the author(s), with first publication rights granted to the journal.

This is an open-access article distributed under the terms and conditions of the Creative Commons Attribution license (http://creativecommons.org/licenses/by/3.0/). 